Vol. 2:27-32, December 2016

DOI: http://dx.doi.org/10.3126/jnarc.v2i0.16118

\title{
Is Investment in Maize Research Balanced and Justified? An Empirical Study
}

\author{
Hari Krishna Shrestha* and Samaya Gairhe \\ Agriculture Economics, Singhdurbar Plaza, Kathmandu \\ *Correspondence: hkshrestha_1@yahoo.com
}

Received September 2015, Revised August 2016; Accepted November 2016

Scientific Editors: Devendra Gauchan, Bal K. Joshi

Copyright $@ 2016$ NARC. Permits unrestricted use, distribution and reproduction in any medium provided the original work is properly cited

\begin{abstract}
The objective of this study was to investigate whether the investment in maize research was adequate and balanced in Nepalese context. Resource use in maize research was empirically studied with standard congruency analysis by using Full Time Equivalent (FTE) of researchers as a proxy measure of investment. The number of researchers involved in maize was 61 but it was only 21.25 on FTE basis, indicating that full time researchers were very few as compared to the cultivated area of maize in the country. Statistical analysis revealed that the investment in maize research was higher in Tarai and lower in the Hills. Congruency index on actual production basis was found low across the eco-zones and even lower across the geographical regions indicating that the investment in maize research was a mismatch and not justified. While adjusted with the equity factor and the research progress factor in the analysis substantial difference was not found in congruency index. This study recommends that substantial increase in investment in maize research is needed with balanced and justified manner across the eco-zones and the geographical regions. Hills need special attention to increase the investment as maize output value is higher in this eco-zone. Eastern and western regions also need increased investment in maize according to their contribution in the output value.
\end{abstract}

Key Words: Eco-zones, Full Time Equivalent, Geographical regions, Investment, Maize

\section{सारांश}

मके बाली अनुसन्धानमा भएको लगानी देश भर पर्याप्त र सन्तुलित थियो कि थिएन जाँच्नु यस अध्ययनको उद्देश्य थियो । अनुसन्धानकर्ताको पूर्ण समय समान (Full Time Equivalent) लाई लगानीको प्रतिनिधि मापन (Proxy measure) को रुपमा लिई स्तरीय कन्तरुएन्सी विश्लेषण ( Congruency Analysis) द्वारा अनुभवसिद्ध अध्ययन(Empirical study) गरिएको थियो । मकैवाली अनुसन्धानमा लागेका ६१ अनुसन्धानकर्ताहरुको समय मुल्यांकन गर्दा केवल २१.२५ पूर्णकालिन अनुसन्धानकर्ता रहेको पाइयो जुन देशको मकैखेती गर्ने क्षेत्रफल को तुलनामा निकै कम मान्न सकिन्छ । तथ्यांक विश्लेषण गर्दा मकै बाली अनुसन्धानको लागि गरिएको स्रोत लगानी तराईमा अधिक पाईयो भने पहाडमा न्यून पाईयो । त्यस्तैगरि, मध्यमान्चलमा अधिक लगानी भएको पाईयो भने अन्य भौगोलिक क्षेत्रहरुमा न्यून पाईयो । वास्तविक उत्पादनलाई आधार मान्दा पारिस्थितिक क्षेत्रहरु (Ecological regions) मा कन्ग्रुएन्सी सूचकांक न्यून पाइयो भने, भौगोलिक क्षेत्र (Geographical regions) मा उक्त सूचकांक अभ न्यून पाइयो र यसले मकै अनुसन्धानमा भएको लगानी सन्तुलित र न्यायिक नभएको पुष्टि हुन्छ। विश्लेषणमा समता र अनुसन्धान प्रगति कारक लाई समायोजन गर्दा भौगोलिक क्षेत्रको कन्तरुएन्सी सचकांकमा खासै भिन्नता पाइएन । अनुसन्धान नतिजाको आधारमा पारिस्थितिक क्षेत्र (Ecological regions) र भौगोलिक क्षेत्रहरु ( Geographical regions) लाई मध्यनजर गरि देश भित्र मकै बजारको मांग पर्ति गर्न सन्तुलित रुपमा मकै अनुसन्धानमा लगानी बद्धि गर्न सिफारिस गरिन्छ । पहाडमा मकैको आर्थिक प्रतिफल धैरै भएको हुँदा सोही आधारमा सो क्षेत्रमा लगानी बृद्धि गर्नु पर्दछ । भौगोलिक क्षेत्रको हकमा पुर्वाज्चल र पश्चिमाज्चल क्षेत्रमा त्यहाँको मकैको आर्थिक योगदानको आधारमा लगानी बढ्दि गर्नु पर्दछ,।

\section{INTRODUCTION}

Agricultural research is a continuous process aimed at enhancing the benefit of producers as well as well-being of consumers by minimizing costs, increasing output, improving product quality and or introducing new products. Investment in agricultural research is important for increasing food production to meet market demand. However, it might take relatively longer period to demonstrate the impact through increased production or quality improvement. In order to allocate research resources efficiently, possibilities of advancing knowledge or technology need to be explored in a particular commodity, problem or discipline. Meanwhile, if the research effort is successful the level of adoption occurring over a given time should be studied (Fuglie 2007). Type of resources and partnerships requiring should also be investigated along with extension strategies to increase the adoption.

Nepal Agricultural Research Council (NARC) is the largest and national mandated agricultural research organization of the country, where number of full time researchers increased from 278 to 338 during 2010-2014 (Rahija et al 2011; Stads et al 2015). The existing human resource in agricultural research was much less than required; about 50 percent of the scientist and 30 percent of the technical officer positions were vacant during 2009-2014. Various institutional constraints, lack of motivation and political interference as common in third world were hindering to attract young, energetic and qualified human resource weakening the organization in retaining the scientists (Stads et al 2015).

It is generally recommended that the spending on agriculture research should be at least 1 percent of agricultural GDP in any country (World Bank 1981), so substantial outcome could be visible. In Nepal, the amount of grant allocated to research depends mainly on the past resource allocation, spending pattern, and total public allocation in whole agriculture sector, but there is no explicit consideration of research priorities, research productivity, or research planning, in general (ITAD 2005). Estimates show that public allocation in agriculture in general, accounts for less than $3 \%$ of the national budget and $4 \%$ of the value of agricultural output in spite of its huge importance in the national economy (Sharma 2009). 
The investment on commodity research should be rational for achieving outcomes to increase the production and productivity. For evaluating investment on commodity research, it is a general practice to examine whether resource allocation is matching or not with the output value of the same commodity. Thus, in this paper we investigate rationality of the resource allocation in maize research to examine whether the investment in eco-zones and geographical regions was adequate and justified.

\section{MATERIALS AND METHODS}

Research cost in general could be derived based on the expenditure incurred in different research projects related to rice, wheat and maize in all the research stations including the commodity research programs. However, proxy research cost was derived based on Full Time Equivalent (FTE) of researchers for congruency analysis in this study. The congruency analysis, a simplest and commonly used tool was employed in this study. The congruency rule maintains that research resource to a commodity should be allocated in proportion to its contribution to the value of production across production environments and geographical regions. The actual prevailing pattern of research resource allocation was compared to an index based on the value of production. Following the equation given by Byerlee and Morris (1993) and Pandey and Pal (2007), the congruency can be measured by,

$C=1-\Sigma\left(R_{i}-V_{i}\right)^{2} \ldots(1)$

Where, $0 \leq \mathrm{C} \leq 1$, with $C=0$ indicating no congruency between the allocation of research resources and value of output of a particular commodity. When $C=1$, it indicates a fully congruent or balanced resource allocation. Congruency increases as the value of $C$ approaches unity. $R_{i}$ is the share of research resources allocated to environment $\mathrm{i}$, and $V_{i}$ is the share of the value of production in the same environment.

The share of the output value $V_{i}$ was calculated as:

$V_{i}=P_{i} W_{i} /\left(\Sigma P_{i} W_{i}\right)-(2)$

Where,

$P_{i}=$ the price of particular commodity in environment $i$

$W_{i}=$ the production of particular commodity in environment $i$

A questionnaire survey was carried out among the 120 researchers working in cereal crops research for their Full Time Equivalent (FTE) involvement in maize crop. The total FTE data was updated in 2014 by reviewing the approved project proposals of researchers along with their time involvement in the maize crop. The information on maize production across the eco-zones and the geographical regions as well as market price of maize was adopted from national statistics (MoAD 2013). Data on the number of total scientists working in rice, wheat and maize and time series data on investment in those crops were obtained from annual program book of NARC. Financial investment in each commodity was derived from operational cost at constant price based on 2001 price.

\section{RESULTS}

The investment trend in three main commodities, maize, wheat and rice was not consistent but found undulating in the time period from 2001 to 2014 (Figure 1). Rice and wheat crops had almost similar trend of investment rice maintaining the higher position, in general except 4 times when the values were very close. Whereas maize crop had reverse trend to some extent, especially during $2004-2008$, when investment in maize exceeded all reaching to highest about 14000 thousand Nepalese Rupees (NRs) in year 2004 (Figure 1). This highest trend in maize research continued till 2008 with very narrow range of undulation reaching approximately 12000 thousands NRs in year 2007. The minimum investment in maize research was in year 2003 when the annual budget declined to about 2000 thousands NRs. This trend also reappeared in years 2009 and 2010 (Figure 1). The trend showed that the investment in rice and wheat went down while the maize had abrupt increase in investment from 2003 onwards (Figure 1). The investment in all the three crops went down in 2003 but afterward it went drastically up in maize leaving rice and wheat at bottom for several years until 2008.

At the constant price investment in rice research was highest in year 2013 reaching about 14000 thousand NRs, while investment on wheat was higher in 2002 which sharply decreased in 2003 and remained almost the same till 2010 and increased again sharply and maintain a platue until 2014 (Figure 1). The investment in all the three crops sharply increased in 2011 with increasing trend up to 2013. The lowest investment in rice was 4 million NRs in 2010. In wheat crop, the investment was less than 3 million Rs in 2006 which went up to 9.8 million Rs. in 2013. In maize, the investment was much less during 2001-2003 but it drastically increased to 14 million in 2004.

A bit large investment in cereal research before 2003 was due to a World Bank supported project AREP (Agriculture Research and Extension Project). From 2003 onwards, maize research had received a Swiss (SDC) funded project HMRP (Hill Maize Research Project) that lasted up to 2008, but rice and wheat research could not receive any substantial funding from the donors. Since 2011, agriculture sector received increased government investment so did the cereal crops research. 


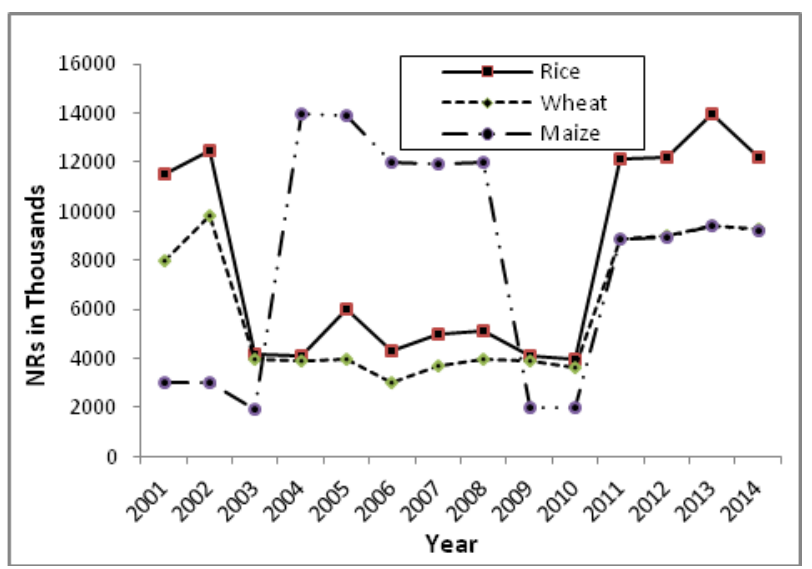

Figure 1. Financial investment in rice, wheat and maize at constant price in Nepal.

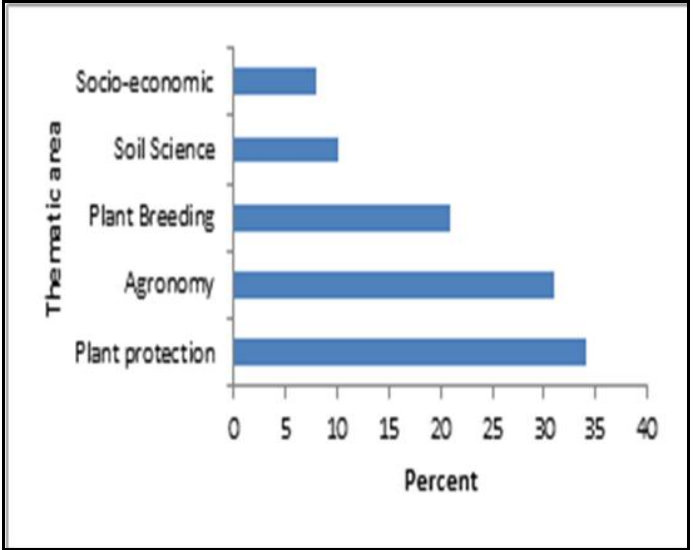

Figure 2. FTE share (\%) of thematic area in maize in year 2014.

Among 332 researchers in NARC in 2014, 115 in rice, 61 in maize, 92 in wheat and 15 represented in finger millet working partly or fully (Table 1). The number of researchers on head count basis was much larger than those on FTE basis, which accounts 38.75 researchers in rice, 21.25 in maize, 27.25 in wheat and 1.80 in finger millet. Regarding the time spent in rice, maize, wheat and finger millet, 34, 35, 30 percent and 11 percent of their total times were consumed in respective commodities.

Table 1. Full Time Equivalent (FTE) of researchers involved in major cereals, 2014

\begin{tabular}{lcccc}
\hline Crop & No of researchers & Total FTE & FTE per researcher & FTE share $(\%)$ \\
\hline Rice & 115 & 38.75 & 0.34 & 43.52 \\
Maize & 61 & 21.25 & 0.35 & 23.86 \\
Wheat & 92 & 27.25 & 0.30 & 30.60 \\
Finger millet & 15 & 1.80 & 0.11 & 2.02 \\
\hline
\end{tabular}

Among the thematic area in maize research, the FTE allocation was largest in plant protection (34\%) followed by agronomic research $(31 \%)$ and plant breeding (21\%). Least investment was done in socioeconomic research in maize (Figure 2). The plant protection thematic area covers both the areas of plant pathology and entomological research in maize. Research on other cross cutting sectors like agricultural engineering, food technology and biotechnology was not carried out for maize during the study period.

\section{Resource Allocation in Maize Research Across the Eco-Zones}

Resource use and production share in maize research across the eco-zones is presented in Table 2 . The congruency index was 0.76 , when FTE share was compared with actual production share, whereas it was 0.78 when the production share was adjusted with research progress. When the production share was adjusted with equity, the congruency index declined to 0.74 . However, the congruency index increased to 0.84 when the production share was fully adjusted with research progress and equity.

Table 2. Resource use and production share in maize research across the eco-zones, 2014.

\begin{tabular}{|c|c|c|c|c|c|}
\hline Parameters & Tarai & Hills & Mountain & Total & Congruency \\
\hline FTE share & 55.53 & 43.06 & 1.41 & 100 & \\
\hline Actual Production share & 18.95 & 71.42 & 9.63 & 100 & 0.76 \\
\hline \multicolumn{6}{|l|}{ Normative Production share } \\
\hline Adjusted production share (research progress) & 20.35 & 70.55 & 9.10 & 100 & 0.78 \\
\hline Adjusted production share (equity) & 17.37 & 72.03 & 10.60 & 100 & 0.74 \\
\hline Fully adjusted production share (research progress and equity) & 26.17 & 70.81 & 3.02 & 100 & 0.84 \\
\hline
\end{tabular}

The congruency index had increased by 2 percent when the production share was adjusted with research progress. This indicated overallocation of resources in Tarai by 35 percent points, whereas it showed under-allocation of resources in hills and mountains by 27 percent points and 8 percent points, respectively. The congruency index of 78 percent had still indicated a mismatch between resource allocations in maize across the eco-zones (Table 2).

When the production share was adjusted with poverty ratio or equity factor, the congruency index declined to 74 percent indicating even more mismatch of resources across eco-zones. This showed that over-allocation of resources in Tarai by 28 percent points whereas under-allocation of resources in hills and mountain by 29 percent points and by 9 percent, respectively. 
Vol. 2: 27-32, December 2016

DOI: http://dx.doi.org/10.3126/jnarc.v2i0.16118

When the production share was adjusted with both research progress and poverty simultaneously, the congruency increased to 84 percent but still indicated a mismatch of resource allocation. This indicated over-allocation of resources in Tarai by 29 percent points, whereas under-allocation of resources in hills and mountain by 28 percent points and by 1.6 percent, respectively.

\section{Resource Allocation in Maize Research Across Geographic Regions}

Resource use and production share in maize research across the geographic regions was compared in Table 3. While FTE share was compared with actual production share, the congruency index was 0.62 but it declined to 0.60 while compared with adjusted production share with research progress. While the production share was adjusted with equity, the congruency index declined to 0.59 . When the production share was fully adjusted with research progress and equity, the congruency index further declined to 0.57.

The congruency analysis showed that there was a large mismatch between FTE share and production share as the congruency index was only 62 percent. There was under-allocation of resources by 17 percent points in eastern region and huge over-allocation of resources by 54 percent points in central region. Under-allocation of resources was found in western, mid-western and far western region by 24,10 and 3 percent points respectively. The main reason behind skewed allocation of resources was due to a number of maize researchers working in crop related disciplinary Divisions in Khumaltar, located in central region. Moreover, a substantial number of maize researchers have been placed in National Maize Research Program, located in central region

The congruency index had declined by 2 percent when the production share was adjusted with research progress. With this low congruency index, the mismatch of resources was amplified with under-allocation by 23 percent points in eastern region and overallocation by 49 percent points in central region. Under-allocation of resources in western, mid-western and far western region was by 33, 12 and 4 percent points respectively.

Table 3. Resource use and production share in maize research across the geographic regions 2014

\begin{tabular}{|c|c|c|c|c|c|c|c|}
\hline Parameters & $\begin{array}{l}\text { Eastern } \\
\text { region }\end{array}$ & $\begin{array}{l}\text { Central } \\
\text { region }\end{array}$ & $\begin{array}{l}\text { Western } \\
\text { region }\end{array}$ & $\begin{array}{l}\text { Mid } \\
\text { West }\end{array}$ & $\begin{array}{l}\text { Far } \\
\text { West }\end{array}$ & $\begin{array}{l}\text { Tota } \\
1\end{array}$ & Congruency \\
\hline FTE share & 11 & 78 & 4 & 5 & 2 & 100 & \\
\hline Actual production share & 28 & 24 & 28 & 15 & 5 & 100 & 0.62 \\
\hline \multicolumn{8}{|l|}{$\begin{array}{l}\text { Normative production share } \\
\text { Adjusted production share (research } \\
\text { progress) }\end{array}$} \\
\hline & 33.92 & 29.07 & 37 & 16.52 & 5.51 & 100 & 0.60 \\
\hline & 35.98 & 28.04 & 35.98 & 22.78 & 7.59 & 100 & 0.59 \\
\hline $\begin{array}{l}\text { Fully adjusted production share (research } \\
\text { progress and equity) }\end{array}$ & 34.84 & 27.15 & 38.01 & 36.27 & 27.20 & 100 & 0.57 \\
\hline
\end{tabular}

\section{DISCUSSION}

Agricultural research usually shows its impact a little later in economy level to general observers and policymakers (Gauchan and Pandey 2011). This might causes poor resource allocation for agricultural research, despite the government declaration of priority given to the agricultural sector in various plans and policies (Yadav 1987, Upadhyay 1996, ITAD 2005, Sharma 2009). To capacitate the agricultural research, investment are required in agricultural education, institutions, human resource development, infrastructures, and research etc., which is unlikely to be developed in short period of time without emphasizing in national agendas and political commitments.

The past research investment in rice, wheat and maize was not based on their output value or research priority setting. The investment trend indicated an erratic pattern of funding in major cereal crops (Figure 1). The main reason behind such erratic trend of investment was funding behavior or interest of donor organizations or countries. A World Bank funded project namely Agricultural Research and Extension Project (AREP) was terminated in 2003 resulting low investment in agricultural research afterwards. Absence of other donor funded projects and existing conflict situation in the country had resulted low investment in whole agricultural research during the period from 2002 to 2010 (Figure 1). However, commencement of Hill Maize Research Project (HMRP) funded by Swiss Government resulted into higher investment in maize research during the period from 2004 to 2008 . Research investment in maize became low during 2009 to 2010 as the Hill Maize Research Project (HMRP) had terminated and government budget in agriculture research was not increased. Not only the maize, but also rice and wheat were less invested during the period as agriculture sector got less priority in resource allocation during post conflict situation of the country until 2011 (Figure 1).

\section{Full Time Equivalent (FTE) of Researchers}

Full Time Equivalent (FTE) is the total time spent in research by a researcher in a commodity (Figure 2). If each of two researchers spends 75 percent time of his or her total time in maize then the FTE becomes 1.5. Congruency analysis could be carried out through proxy measure of resource allocation by using FTE of the researchers in particular crop, domain or environment. The commodity research does not represent only direct research such as agronomic or breeding but also represents disciplinary researches such as agricultural engineering, food technology, agricultural environment and other sectors which are associated to that commodity.

Congruency analysis was carried out to know whether the resource allocation in maize was matched with its output value. Full Time Equivalent (FTE) share of researchers in maize crop was compared with production share of the crop (Table 2). A production share was 
considered as an important factor and an analysis was carried out on the basis of actual production share as well as adjusted production share of maize. The production share was derived based on actual production of the commodity and its market price. The production share was adjusted with research progress and equity as described in research methods. Other factors such as poverty, employment, health and environment could be considered for adjustment in research priority assessment and impact study (Fuglie 2007). The actual production and market price of maize was adopted from national statistics (MoAD 2013). The actual production share of maize was adjusted with research progress and equity factor for deriving its normative production share. The research progress factor was estimated based on subjective judgment in consultation with experienced maize breeders and agronomists. The equity factor was estimated based on poverty ratio found in specific maize domain.

\section{Resource Allocation in Maize Research Across the Eco-Zones}

Total FTE share of maize was split in three eco-zones namely Tarai, hills and mountains according to real time spent in maize by the researchers in the respective eco-zone. Similarly, production share of maize was derived for all the eco-zones according to quantity produced and their market value in each eco-zone. For production share, output value of maize crop was derived by multiplying its production with the market price.

Based on the experience and knowledge of maize researchers, the increase in maize productivity in next ten years was estimated as 25 percent in Tarai and 15 percent in the hills and 10 percent in the mountains. The Tarai eco-zone of Nepal has higher potential of productivity increase due to relatively good soil fertility, abundance of water for irrigation and increasing adoption of hybrid maize. The yield gains in rice relative to the current values were estimated as 30 percent for Tarai, 20 percent for hills, and 10 percent for mountains (Gauchan and Pandey 2011). The poverty ratios for the hills and mountains were estimated as 15 percent and 20 percent higher, respectively as compared to that in Tarai eco-zone. Thus the poverty weight was used as 1 for the Tarai, 1.15 for the hills and 1.20 for the mountains based on the poverty ratios.

The congruency analysis showed that there was a large mismatch of resource allocation as the congruency index was only 76 percent (Table 2). One of the reasons behind this skewed or mismatch of resources was a number of maize researchers working in National Maize Research Program located in Tarai. The maize researchers were not proportionately distributed among the eco-zones as per their contribution in the output value.

\section{Resource Allocation in Maize Research Across Geographic Regions}

Total FTE share of maize was split in five geographic regions from east to far west according to real time spent in maize by the researchers in the respective region (Table 3). Similarly, production share of maize was derived for all the geographic regions according to production quantity and its market value in each geographic region. To derive production share, output value of maize crop was derived by multiplying its production with the market price.

Based on potential of pipeline technologies and consultation with experienced researchers, the maize productivity was expected to increase in next ten years by 20 percent each in eastern, central and western region, whereas it would be increased by 30 percent each in mid-western and far western region. Because, mid-western and far western region have large scope and potential in future with increased access to technology and inputs (Table 3). Moreover, unused natural resources of mid-western and far western region at present could be useful in future to increase production and productivity of maize.

Poverty ratio was estimated according to geographic regions. Considering the lowest poverty in central region, the weight given to this region was unity or 1 as a benchmark to compare poverty with other regions. Considering ten percent higher poverty in eastern and western region, the weight given to both of these regions was 1.10 . Considering thirty percent higher poverty in mid-western region and far western region, the weight given to both of these regions was 1.30.

In the Table 3, congruency percentage was quite low in all the cases of actual and normative production share because of mismatch in resource allocation across the regions. The investment was not based on their maize output value. The long term investment in maize research was erratic and influenced by donor's interest as well as inconsistency of government priority. Among the thematic area, Plant Protection had highest FTE share, whereas Socioeconomic Research had the least FTE share. The congruency index was low across the eco-zones and even lower across the geographical regions indicating there was largely mismatch in investment in maize research (Table 2 and 3). There was no substantial change in congruency index while the actual production share was adjusted with factors like equity and research progress. The study suggested that the substantial increase in investment in maize research was needed with balanced and justified manner across the eco-zones and the geographical regions. By eco-zones, hills had larger production share but received low investment resulting into low congruency percentage. By geographical regions, eastern and western regions had low investment despite their significant contribution in the maize output value. Special attention needs on maize research in Hills for increased investment among the eco-zones whereas priority should be given in central region for the investment among geographical regions. The eastern and western region along with mid-western and far western regions deserve substantial investment in maize research.

\section{CONCLUSION}

Investment in maize research had witnessed ups and downs over the last fourteen years. Donor funded projects had a substantial role in the total research investment in the cereal crops in the country. Nepal's agriculture sector had experienced inconsistency in government funding and research priority and so did commodity programs over the years. The research investment in the past was basically dependent on immediate need and short term priority. Rather, it should have been based on scientific and logical norms with long term strategy. Output value of commodity in the region or in the eco-zone is a logical basis to invest in its research. Based on the study 
findings, it could be concluded that maize research was over-invested in central region and Tarai eco-zone whereas it was under-invested in all other regions and mid hill eco-zone. Substantial increase in investment in maize research was required in eastern region, western region and mid hill eco-zone. Mid-western region and far western region also need increase in investment though not as much as in eastern and western regions. In general, the present result implies that it is not only the maize research, but other commodity researches too need larger investment for securing food and nutritional security in the country.

\section{ACKNOWLEDGEMENT}

This study was partly supported by IFPRI funding especially in researchers' survey on their full time equivalent in particular crops. Relevant information was collected by using NARC human resources especially from Planning Division without any separate budget expenditure. The authors are grateful to IFPRI and NARC management for providing the opportunity and moral support to carry out this study. The reviewers contributions on finalization of this paper is highly appreciated.

\section{REFERENCES}

Byerlee D and M Morris. 1993. Research for marginal environments: Are we under-invested? Food Policy 18: 381-393.

Fuglie K. 2007. Research Priority Assessment for the CIP 2005-2015 Strategic Plan: Projecting Impacts on Poverty, Employment, Health and Environment. International Potato Center (CIP), Lima, Peru. 120p.

Gauchan D and S Pandey. 2011. Is investment in rice research in Nepal adequate and balanced across production environments? Some empirical evidence. Quarterly Journal of International Agriculture 50(4): 305-324.

ITAD. 2005. A review of research impact, responsiveness and future priorities in the agriculture sector in Nepal. Final report, ITAD UK /New ERA, Kathmandu, Nepal. 132p.

MoAD. 2013. Statistical Information on Nepalese Agriculture. Ministry of Agriculture Development. Singh Durbar, Kathmandu, Nepal.

Pandey S and S Pal. 2007. Are less-favored environments over-invested? The case of rice research in India. Food Policy 32: 606-623.

Rahija M, HK Shrestha, GJ Stads and RB Bhujel. 2011. Recent development in public agricultural research. Agricultural science and technology indicators: Nepal. International Food Policy Research Institute, Washington DC. 12p.

Sharma, S. 2009. Income inequality in Nepal. Chapter 4. UNDP Regional Center. Colombo.

Stads GJ, HK Shrestha, HK Manandhar and L Gao. 2015. Agricultural R\&D Indicators Factsheet Nepal. ASTI/IFPRI/NARC. 4p.

Upadhyay HK. 1996. Rice research in Nepal: Current state and future priorities. In: Rice research in Asia : Progress and priorities edited by Evenson, R.E., Herdt, R.W. and Hossain, M. CAB International/International Rice Research Institute, Philippines. pp. 52-68.

World Bank.1981. Agriculture Research: Sector policy paper. Washington, D.C. 62p.

Yadav RP. 1987. Agricultural research in Nepal. Resource allocation, structure and incentives. Research Report 62. International Food Policy Research Institute, USA. 87p. 